\title{
Serum Brain-Derived Neurotrophic Factor in Euthymic Bipolar Patients on Prophylactic Lithium Therapy
}

\author{
A. Suwalska ${ }^{\text {a }}$ M. Sobieska ${ }^{\text {b J.K. Rybakowski }}{ }^{a}$

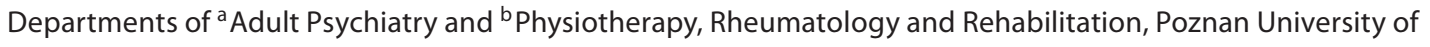 \\ Medical Sciences, Poznan, Poland
}

\section{Key Words}

Bipolar disorder • Lithium • Brain-derived neurotrophic factor

\begin{abstract}
Aim: The aim of the study was to evaluate serum brain-derived neurotrophic factor (BDNF) levels in a group of euthymic bipolar patients on long-term prophylactic lithium treatment and to delineate putative relationships between lithium efficacy and BDNF concentrations. Methods: $141 \mathrm{eu}-$ thymic bipolar patients (51 male, 90 female) on long-term lithium treatment were studied. Three categories of prophylactic lithium response were delineated: excellent lithium responders (ER; 30 patients), partial lithium responders (PR; 61 patients) and lithium nonresponders (NR; 50 patients). The control group consisted of 75 age- and gender-matched healthy subjects. Results: The lithium-treated patients as a whole group had lower BDNF levels compared to the healthy controls. However, after breaking down the patients into ER, PR and NR, it appeared that only NR had significantly lower BDNF levels compared with the healthy control subjects. No association between the age of the patients, duration of bipolar illness, and serum lithium and BDNF levels was found. Conclusion: The results point to a relationship between lithium prophylactic efficacy and plasma BDNF levels in euthy-
\end{abstract}

mic bipolar patients where lithium NR had reduced BDNF levels. These findings suggest that serum BDNF is associated with lithium efficacy in bipolar disorder.

Copyright $\odot 2010$ S. Karger AG, Basel

\section{Introduction}

Brain-derived neurotrophic factor (BDNF) is a member of the nerve growth factor family, which is involved in neuronal survival, differentiation, synaptogenesis and maintenance [1]. BDNF has been proposed as a candidate molecule in the pathophysiology of affective disorders [2-4].

Furthermore, an association between cognitive performance and BDNF gene, specific for bipolar illness, has been observed [5]. BDNF is present in the central nervous system and in peripheral blood, where it is stored in platelets and released in the plasma via activation of the clotting process [6]. Serum BDNF levels have been reported to significantly decrease in patients with major depressive disorder during acute episode [7-10] and to return to normal during remission [11]. The results of studies on peripheral BDNF levels in bipolar disorder (BD) are presented in table 1.

\section{KARGER}

Fax +4161306 1234 E-Mail karger@karger.ch www.karger.com

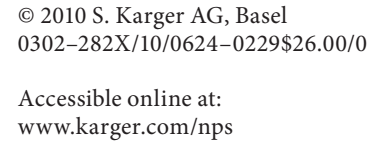

Prof. Janusz K. Rybakowski

Department of Adult Psychiatry, Poznan University of Medical Sciences ul. Szpitalna $27 / 33$

PL-60-572 Poznan (Poland)

Tel. +48 61847 5087, Fax +48 61848 0392, E-Mail rybakows@ wlkp.top.pl 
Table 1. Studies on serum BDNF in BD

\begin{tabular}{|c|c|c|c|}
\hline Author & Studied group & Serum BDNF levels & Clinical correlates \\
\hline $\begin{array}{l}\text { Cunha } \\
\text { et al. [12] }\end{array}$ & $\begin{array}{l}32 \text { manic, } 21 \text { depressed, } 32 \\
\text { euthymic } \mathrm{BD}-\mathrm{I} \text { patients and } \\
\text { matched healthy controls }\end{array}$ & $\begin{array}{l}\text { BDNF levels decreased in manic and } \\
\text { depressed BD patients compared with } \\
\text { euthymic patients and controls; no decrease } \\
\text { in BDNF in euthymic patients }\end{array}$ & $\begin{array}{l}\text { BDNF levels negatively } \\
\text { correlated with severity of } \\
\text { manic and depressive } \\
\text { symptoms }\end{array}$ \\
\hline $\begin{array}{l}\text { Machado-Vieira } \\
\text { et al. [13] }\end{array}$ & $\begin{array}{l}30 \text { manic patients, } 30 \\
\text { matched healthy controls }\end{array}$ & $\begin{array}{l}\text { Mean BDNF levels significantly decreased } \\
\text { in drug-free/naive patients compared to } \\
\text { healthy controls }\end{array}$ & $\begin{array}{l}\text { Severity of mania negatively } \\
\text { correlated with plasma } \\
\text { BDNF levels }\end{array}$ \\
\hline $\begin{array}{l}\text { Kauer-Sant'Anna } \\
\text { et al. [14] }\end{array}$ & $\begin{array}{l}163 \text { consecutive BD } \\
\text { outpatients }\end{array}$ & $\begin{array}{l}\text { Bipolar patients with a history of TE - } \\
\text { increased prevalence of alcohol and anxiety } \\
\text { comorbidity, and lower levels of serum } \\
\text { BDNF ( }<<0.01 \text { ) compared to those without } \\
\text { a history of TE }\end{array}$ & - \\
\hline $\begin{array}{l}\text { Gama } \\
\text { et al. [15] }\end{array}$ & $\begin{array}{l}60 \text { patients with } \\
\text { schizophrenia, } 30 \text { euthymic } \\
\text { BD patients, } 26 \text { healthy } \\
\text { controls }\end{array}$ & $\begin{array}{l}\text { BDNF levels significantly higher in SZ } \\
\text { patients }(\mathrm{p}<0.001) \text { when compared to } \\
\text { either controls or euthymic BD patients }\end{array}$ & - \\
\hline $\begin{array}{l}\text { Monteleone } \\
\text { et al. [16] }\end{array}$ & $\begin{array}{l}24 \text { euthymic UD, } 17 \text { euthymic } \\
\text { BD-I, } 11 \text { euthymic BD-II and } \\
11 \text { depressed UD patients, } 22 \\
\text { drug-free healthy controls ( } 15 \\
\text { patients drug treated, } \\
\text { remaining ones drug free for } \\
\text { at least } 4 \text { weeks) }\end{array}$ & $\begin{array}{l}\text { Compared to healthy controls, serum } \\
\text { BDNF concentrations were significantly } \\
\text { reduced in all patient groups with no } \\
\text { significant difference among them; } \\
\text { decreased serum BDNF levels in euthymic } \\
\text { patients with UD, BD-I and BD-II }\end{array}$ & $\begin{array}{l}\text { Drug treatments and } \\
\text { comorbid psychiatric } \\
\text { disorders had no effect on } \\
\text { lowered circulating BDNF } \\
\text { levels in affective patients }\end{array}$ \\
\hline $\begin{array}{l}\text { de Oliveira } \\
\text { et al. [17] }\end{array}$ & $\begin{array}{l}22 \text { manic and depressed } \\
\text { drug-free, } 22 \text { medicated BD-I } \\
\text { patients, } 22 \text { matched controls }\end{array}$ & $\begin{array}{l}\text { BDNF levels in drug-free and medicated BD } \\
\text { patients decreased when compared to } \\
\text { controls; BDNF levels did not differ } \\
\text { between medicated and drug-free BD } \\
\text { patients }\end{array}$ & $\begin{array}{l}\text { Results suggest that } \\
\text { correlation of lower serum } \\
\text { BDNF with BD mood } \\
\text { episodes is maintained even } \\
\text { in medicated patients }\end{array}$ \\
\hline $\begin{array}{l}\text { Fernandes } \\
\text { et al. [18] }\end{array}$ & $\begin{array}{l}10 \text { depressed MDD, } 40 \\
\text { depressed BD-I patients, } 30 \\
\text { healthy controls }\end{array}$ & $\begin{array}{l}\text { BDNF levels in depressed BD patients lower } \\
\text { compared to MDD patients and controls }\end{array}$ & $\begin{array}{l}\text { Serum BDNF levels as an } \\
\text { adjunct tool to discriminate } \\
\text { bipolar from unipolar } \\
\text { depression }\end{array}$ \\
\hline $\begin{array}{l}\text { Tramontina } \\
\text { et al. [19] }\end{array}$ & $\begin{array}{l}10 \text { BD patients with acute } \\
\text { mania prospectively } \\
\text { examined at inpatient unit } \\
\text { admission and discharge }\end{array}$ & $\begin{array}{l}\text { BDNF levels decreased in BD patients } \\
\text { during mania compared to controls; this } \\
\text { difference was no longer significant after } \\
\text { treatment; sharp increase in BDNF levels } \\
\text { after treatment of acute mania }\end{array}$ & $\begin{array}{l}\text { BDNF serum levels may be } \\
\text { associated with treatment } \\
\text { response in acute mania }\end{array}$ \\
\hline $\begin{array}{l}\text { Kauer-Sant'Anna } \\
\text { et al. [20] }\end{array}$ & $\begin{array}{l}60 \text { patients with BD-I, } \\
60 \text { matched healthy controls }\end{array}$ & $\begin{array}{l}\text { BDNF decreased only in patients in late } \\
\text { stage of BD; BDNF levels significantly lower } \\
\text { in later stage than early stage of BD }\end{array}$ & $\begin{array}{l}\text { BDNF levels negatively } \\
\text { correlated with length of } \\
\text { illness }\end{array}$ \\
\hline
\end{tabular}

$\mathrm{MDD}=$ Major depressive disorder; TE = traumatic events; $\mathrm{SZ}=$ schizophrenia; UD = unipolar depression.

In most studies performed on bipolar patients, serum BDNF levels have been significantly reduced both during depressive and manic episodes, and negatively correlated with the severity of such an acute episode. Moreover, the BDNF levels have exhibited a tendency toward returning to normal after successful pharmacological treatment and have remained normal during euthymia $[12,13,16$, 19, 21].

Preclinical studies suggest that the expression of BDNF might be a downstream target of antidepressant 
treatments and mood stabilizers such as lithium and valproate. BDNF exerts antidepressant activity in animal models of depression [22, 23]. Antidepressants and chronic electroconvulsive treatments increase the expression of BDNF and its receptor in rat brain $[24,25]$. Several studies have also demonstrated that lithium may increase the BDNF content in rat hippocampus and frontal cortex [26-29], which suggests that the regulation of neurotrophic factors might be associated with pharmacological effects of lithium [30].

Plasma BDNF levels in depressed patients significantly increase after antidepressant treatment; however, in some studies, such an increase has been observed only in groups of responders to treatment, while the change in nonresponders was not significant $[9,31-34]$. That may suggest that antidepressant response may be associated with the increase in BDNF levels. Similarly, a decrease in plasma BDNF protein has been found in BD patients during acute (manic and depressive) episodes but not in euthymia [12], suggesting that the regulation of BDNF might be implicated in mood stabilization. Molecular genetic studies performed in Poznan have revealed that the effect of lithium prophylaxis is associated with the polymorphisms of the BDNF gene $[35,36]$.

A possible relationship between lithium prophylactic response and serum BDNF levels has not been investigated so far. The aim of this study was to assess whether there existed a relationship between the prophylactic efficacy of lithium and serum BDNF concentration.

\section{Methods}

\section{Subjects}

A total of 141 patients (51 male, 90 female), aged 30-77 years (mean \pm SD: $53.7 \pm 12.7$ years) with bipolar affective disorders attending the Outpatient Lithium Clinic at the Department of Psychiatry of the Poznan University of Medical Sciences were studied. A consensus diagnosis by 2 psychiatrists was made for each patient, according to DSM-IV criteria (Structured Clinical Interview for DSM-IV Axis I Disorders) [37]. The patients had been treated with lithium carbonate for at least 5 years $(5-27$ years; mean: 15.7 years). The patients had been attending the same outpatient clinic for the entire period of lithium administration. The serum concentration of lithium had been maintained in the range between 0.5 and $0.8 \mathrm{mmol} / \mathrm{l}$. The course of illness was assessed retrospectively, based on the analysis of medical outpatient charts, inpatient records and semi-structured interviews, as described previously [35]. On the day of study, all patients were euthymic, defined on the 17-item Hamilton Depression Rating Scale [38] as a score of 7 or less, and on the Young Mania Rating Scale [39] as a score of 7 or less.

BDNF in Bipolar Patients on Lithium
The efficacy of lithium treatment was assessed according to the following criteria: excellent lithium responders (ER) had no affective episodes on lithium; partial lithium responders (PR) showed a $50 \%$ reduction in the episode index (number of episodes per year compared to pre-lithium period), and lithium nonresponders (NR) showed $\mathrm{a}<50 \%$ reduction, no change or worsening on the episode index. To all ER, lithium had been given as a monotherapy. Among the remaining patients, 20 had been concomitantly receiving carbamazepine (PR: 6; NR: 14), 9 valproates (PR: 4; NR: 5), 15 antidepressant drugs (PR: 7; NR: 8) and 14 neuroleptic drugs (PR: 4; NR: 10) for a period of several years. None of the patients was treated with electroconvulsive therapy. There were no pregnancies in patients studied during lithium treatment, either.

Seventy-five healthy controls were matched by age and gender. The control subjects had no history of major psychiatric disorders, dementia, mental retardation and severe/unstable somatic diseases.

The study was approved by the ethics committee at the Poznan University of Medical Sciences. All subjects gave their written consent after the nature of the procedures had been fully explained to them.

\section{BDNF Assessment}

First, $10 \mathrm{ml}$ of blood was drawn from each subject by venipuncture into a free-anticoagulant vacuum tube for biochemical analyses. BDNF serum levels were measured using a commercial kit of sandwich ELISA according to the manufacturer's instruction (Quantikine; R\&D Systems Inc., Minneapolis, Minn., USA). All the assays of BDNF levels were performed blind to the subjects' clinical response to lithium and to their status (ER, PR and NR).

\section{Statistical Analyses}

All statistical analyses were carried out by Statistica version 8.0 for Windows. As most of the variables investigated were not normally distributed, nonparametric tests were employed. Intergroup differences were assessed by the Mann-Whitney test (2-group comparisons) and Kruskal-Wallis ANOVA (comparisons among more than 2 groups). All results were expressed as means and SD.

\section{Results}

In our group, 30 patients (21.3\%) were classified as ER, 61 patients (43.3\%) as PR and 50 patients (35.4\%) as NR to lithium treatment. The clinical characteristics of the group of patients are presented in table 2 .

The age at the onset of illness, duration of treatment with lithium as well as the number of affective episodes before lithium treatment did not differ between these 3 subgroups of patients. ER did not have any affective episodes on lithium, and the number of affective episodes during lithium treatment was greater in NR compared to PR. NR had a lower lithium dose compared to the re-

Neuropsychobiology 2010;62:229-234 
Table 2. Clinical characteristics of lithium-treated bipolar patients and controls

\begin{tabular}{lccccc}
\hline & Patients $(\mathrm{n}=141)$ & $\mathrm{ER}(\mathrm{n}=30)$ & PR $(\mathrm{n}=61)$ & NR $(\mathrm{n}=50)$ & Controls $(\mathrm{n}=75)$ \\
\hline M:F ratio, $\mathrm{n}$ & $51: 90$ & $11: 19$ & $18: 43$ & $22: 28$ & $23: 52$ \\
Age, years & $53.7 \pm 12.7$ & $58.1 \pm 13.3$ & $53.5 \pm 12.0$ & $51.3 \pm 12.7$ & $55.7 \pm 11.7$ \\
Duration of illness, years & $24.4 \pm 10.8$ & $24.9 \pm 12.6$ & $22.9 \pm 10.2$ & $25.7 \pm 10.0$ & - \\
Duration of lithium treatment, years & $15.7 \pm 8.9$ & $14.8 \pm 8.7$ & $16.7 \pm 8.6$ & $15.2 \pm 9.6$ & - \\
Number of episodes before lithium & $7.1 \pm 5.2$ & $7.5 \pm 4.2$ & $7.6 \pm 6.7$ & $6.3 \pm 3.4$ & - \\
Number of episodes on lithium & $5.2 \pm 6.1$ & $0.0 \pm 0.0$ & $4.6 \pm 3.3$ & $10.4 \pm 7.2^{1,2}$ & - \\
Lithium carbonate dose, mg/day & $1,035.4 \pm 227.6$ & $1,042.9 \pm 249.5$ & $1,057.1 \pm 212.3$ & $992.3 \pm 239.7^{1,2}$ & - \\
Serum lithium level, mmol/l & $0.67 \pm 0.06$ & $0.65 \pm 0.05$ & $0.67 \pm 0.07$ & $0.68 \pm 0.07$ & - \\
\hline
\end{tabular}
test).

Values denote means \pm SD. ${ }^{1} \mathrm{p}<0.01$, difference between ER and NR. ${ }^{2} \mathrm{p}<0.01$, difference between PR and NR (Mann-Whitney

Table 3. Serum BDNF levels in lithium-treated bipolar patients and controls

\begin{tabular}{llllll}
\hline & $\begin{array}{l}\text { Patients } \\
(\mathrm{n}=141)\end{array}$ & $\begin{array}{l}\text { Controls } \\
(\mathrm{n}=75)\end{array}$ & $\begin{array}{l}\text { ER } \\
(\mathrm{n}=30)\end{array}$ & $\begin{array}{l}\text { PR } \\
(\mathrm{n}=61)\end{array}$ & $\begin{array}{l}\text { NR } \\
(\mathrm{n}=50)\end{array}$ \\
\hline Serum BDNF level, ng/ml & $24.2 \pm 17.0^{1}$ & $27.4 \pm 10.4$ & $26.7 \pm 16.8$ & $26.5 \pm 17.9$ & $21.9 \pm 15.5^{2}$ \\
\hline
\end{tabular}

Values denote means $\pm \mathrm{SD} .{ }^{1} \mathrm{p}=0.051$, difference between lithium-treated patients and healthy controls; ${ }^{2} \mathrm{p}=0.025$, difference between NR and healthy controls.

Table 4. Correlations of serum BDNF levels with clinical factors

\begin{tabular}{lllrr}
\hline & $\begin{array}{l}\text { Lithium group } \\
(\mathrm{n}=141)\end{array}$ & $\begin{array}{l}\text { ER } \\
(\mathrm{n}=30)\end{array}$ & \multicolumn{1}{l}{ PR } \\
$(\mathrm{n}=61)$ & \multicolumn{1}{l}{$\begin{array}{l}\mathrm{NR} \\
(\mathrm{n}=50)\end{array}$} \\
\hline Age & $-0.07(0.39)$ & $0.01(0.98)$ & $-0.17(0.19)$ & $-0.05(0.71)$ \\
Duration of illness & $-0.18(0.09)$ & $-0.15(0.46)$ & $-0.25(0.15)$ & $-0.16(0.40)$ \\
Duration of lithium treatment & $-0.16(0.14)$ & $-0.09(0.65)$ & $-0.18(0.31)$ & $-0.17(0.37)$ \\
Number of episodes before lithium & $-0.05(0.61)$ & $-0.30(0.14)$ & $0.12(0.50)$ & $-0.09(0.64)$ \\
Number of episodes on lithium & $-0.05(0.63)$ & & $-0.06(0.71)$ & $0.17(0.36)$ \\
Serum lithium level & $0.04(0.80)$ & $-0.09(0.75)$ & $-0.23(0.34)$ & $0.46(0.10)$ \\
\hline
\end{tabular}

Values denote Spearman's $\rho$ with p in parentheses.

maining lithium groups; however, the plasma lithium level was similar in all lithium groups.

A comparison of the BDNF levels in the patients with various responses to lithium treatment with the controls is presented in table 3 .

The lithium-treated patients as a whole group had lower BDNF levels compared to the healthy controls ( $\mathrm{p}=$ 0.051; Mann-Whitney test). However, after breaking down the patients into ER, PR and NR, it appeared that only NR had significantly lower BDNF levels compared with healthy control subjects ( $\mathrm{p}=0.025$; Mann-Whitney test). The serum BDNF levels of ER and PR were similar to those of the healthy controls.

The correlation of serum BDNF levels with clinical factors is presented in table 4 . No associations of BDNF levels with the age of the patients, duration of bipolar illness and clinical course before and during lithium treatment, or with lithium level were found. 
In the group of NR, no relationships between serum lithium level, the use of additional medications and serum carbamazepine or valproic acid levels were found.

\section{Discussion}

The main finding of our study is to have demonstrated that in euthymic bipolar patients who did not benefit from lithium prophylactic treatment, serum BDNF levels were significantly lower than in healthy controls. On the other hand, in ER and PR, the levels were comparable to those of healthy subjects.

The results obtained may correspond to other pharmacological studies showing the relationship between BDNF level and the therapeutic response to drugs used in mood disorders. In major depressive disorder, normalization of BDNF levels has been associated with clinical response to antidepressant treatment [9, 32-34]. In BD, it may also be inferred that, while BD patients in remission have a serum level of BDNF similar to that of healthy controls, and the BDNF levels of patients during mania or depression are reduced, a normalization of BDNF levels might be connected with clinical response to pharmacological treatment $[12,40]$.

On the other hand, the finding of this study may also correspond to the results of our previous studies measuring the association between lithium response and cognitive and neuropsychological function in euthymic patients on lithium. The study by Rybakowski et al. [5] shows that, compared with healthy controls, cognitive functions as measured by the Wisconsin Card Sorting Test are preserved in ER and PR, but significantly impaired in NR. Similarly, in the study by Suwalska et al. [41], a sustained attention deficit measured during eu- thymia was significantly smaller in ER than in PR and NR.

These findings suggest that serum BDNF is associated with lithium efficacy in $\mathrm{BD}$, but the causation has not been fully elucidated. BDNF could be involved in the mechanism of lithium mood-normalizing action, or the response to lithium may lead to changes in BDNF levels.

We did not find associations between BDNF levels and patients' age, duration of illness, number of episodes before and during lithium treatment, and serum lithium level. This finding is in accordance with the study by Monteleone et al. [16], in which no significant correlations have been found between serum BDNF levels and age of controls and patients, age at the onset of illness, duration of illness and number of depressive episodes either in the entire patient sample or in each diagnostic group. We did not confirm the results of the study by Kauer-Sant'Anna et al. [20], in which BDNF levels were negatively correlated with length of illness.

A limitation of our study could be the lack of assessment of serum BDNF levels in bipolar patients before commencement of lithium treatment. On the other hand, the length of lithium treatment allowed to precisely assess the quality of the lithium prophylactic effect in all patients. Our findings showing decreased serum BDNF levels in $\mathrm{BD}$ patients who are unresponsive to prophylactic lithium may support the hypothesis of a role of BDNF in the therapeutic action of lithium in BD.

\section{Acknowledgment}

This research was supported by the National Committee for Scientific Research (KBN), grant No. 2PO5B 04430.

\section{References}

1 Webster MJ, Herman MM, Kleinman JE, Shannon Weickert C: BDNF and trkB mRNA expression in the hippocampus and temporal cortex during the human lifespan. Gene Expr Patterns 2006;6:941-951.

-2 Sklar P, Gabriel SB, McInnis MG, Bennett P, Lim YM, Tsan G, Schaffner S, Kirov G, Jones I, Owen M, Craddock N, DePaulo JR, Lander ES: Family-based association study of 76 candidate genes in bipolar disorder: BDNF is a potential risk locus. Mol Psychiatry 2002;7: 579-593.
Neves-Pereira M, Mundo E, Muglia P, King N, Macciardi F, Kennedy JL: The brain-derived neurotrophic factor gene confers susceptibility to bipolar disorder: evidence from a family-based association study. Am J Hum Genet 2002;71:651-655.

4 Lohoff FW, Sander T, Ferraro TN, Dahl JP, Gallinat J, Berrettini WH: Confirmation of association between the Val66Met polymorphism in the brain-derived neurotrophic factor (BDNF) gene and bipolar I disorder. Am J Med Genet B Neuropsychiatr Genet 2005;139:51-53.
5 Rybakowski JK, Borkowska A, Skibinska M, Hauser J: Illness-specific association of Val$66 \mathrm{Met}$ BDNF polymorphism with performance on Wisconsin Card Sorting Test in bipolar mood disorder. Mol Psychiatry 2006; 11:122-124.

6 Fujimura H, Altar CA, Chen R, Nakamura T, Nakahashi T, Kambayashi J, Sun B, Tandon $\mathrm{NN}$ : Brain-derived neurotrophic factor is stored in human platelets and released by agonist stimulation. Thromb Haemost 2002; 87:728-734. 
7 Karege F, Perret G, Bondolfi G, Schwald M, Bertschy G, Aubry JM: Decreased serum brain-derived neurotrophic factor levels in major depressed patients. Psychiatry Res 2002;109:143-148.

8 Karege F, Bondolfi G, Gervasoni N, Schwald M, Aubry JM, Bertschy G: Low brain-derived neurotrophic factor (BDNF) levels in serum of depressed patients probably results from lowered platelet BDNF release unrelated to platelet reactivity. Biol Psychiatry 2005;57: 1068-1072.

9 Gönül AS, Akdeniz F, Taneli F, Donat O, Eker C, Vahip S: Effect of treatment on serum brain-derived neurotrophic factor levels in depressed patients. Eur Arch Psychiatry Clin Neurosci 2005;255:381-386.

-10 Shimizu E, Hashimoto K, Okamura N, Koike K, Komatsu N, Kumakiri C, Nakazato M, Watanabe H, Shinoda N, Okada S, Iyo M: Alterations of serum levels of brain-derived neurotrophic factor (BDNF) in depressed patients with or without antidepressants. Biol Psychiatry 2003;54:70-75.

$\checkmark 11$ Neumeister A, Yuan P, Young TA, Bonne O, Luckenbaugh DA, Charney DS, Manji H: Effects of tryptophan depletion on serum levels of brain-derived neurotrophic factor in unmedicated patients with remitted depression and healthy subjects. Am J Psychiatry 2005; 162:805-807.

-12 Cunha AB, Frey BN, Andreazza AC, Goi JD, Rosa AR, Goncalves CA, Santin A, Kapczinski F: Serum brain-derived neurotrophic factor is decreased in bipolar disorder during depressive and manic episodes. Neurosci Lett 2006;398:215-219.

-13 Machado-Vieira R, Dietrich MO, Leke R, Ceresér VH, Zanatto V, Kapczinski F, Souza DO, Portela LV, Gentil V: Decreased plasma brain-derived neurotrophic factor levels in unmedicated bipolar patients during manic episode. Biol Psychiatry 2007;61:142-144.

-14 Kauer-Sant'Anna M, Tramontina J, Andreazza AC, Ceresér K, da Costa S, Santin A, Yatham LN, Kapczinski F: Traumatic life events in bipolar disorder: impact on BDNF levels and psychopathology. Bipolar Disord 2007;9(suppl 1):128-135.

-15 Gama CS, Andreazza AC, Kunz M, Berk M, Belmonte-de-Abreu PS, Kapczinski F: Serum levels of brain-derived neurotrophic factor in patients with schizophrenia and bipolar disorder. Neurosci Lett 2007;420:4548.

-16 Monteleone P, Serritella C, Martiadis V, Maj M: Decreased levels of serum brain-derived neurotrophic factor in both depressed and euthymic patients with unipolar depression and in euthymic patients with bipolar I and II disorders. Bipolar Disord 2008;10:95-100.
17 de Oliveira GS, Ceresér KM, Fernandes BS, Kauer-Sant'Anna M, Fries GR, Stertz L, Aguiar B, Pfaffenseller B, Kapczinski F: Decreased brain-derived neurotrophic factor in medicated and drug-free bipolar patients. J Psychiatr Res 2009;43:1171-1174.

18 Fernandes BS, Gama CS, Kauer-Sant'Anna M, Lobato MI, Belmonte-de-Abreu P, Kapczinski F: Serum brain-derived neurotrophic factor in bipolar and unipolar depression: a potential adjunctive tool for differential diagnosis. J Psychiatr Res 2009;43:1200-1204.

19 Tramontina JF, Andreazza AC, KauerSant'Anna M, Stertz L, Goi J, Chiarani F, Kapczinski F: Brain-derived neurotrophic factor serum levels before and after treatment for acute mania. Neurosci Lett 2009; 452:111-113.

20 Kauer-Sant'Anna M, Kapczinski F, Andreazza AC, Bond DJ, Lam RW, Young LT, Yatham LN: Brain-derived neurotrophic factor and inflammatory markers in patients with early- vs late-stage bipolar disorder. Int J Neuropsychopharmacol 2009;12:447-458.

21 Kapczinski F, Frey BN, Kauer-Sant'Anna M, Grassi-Oliveira R: Brain-derived neurotrophic factor and neuroplasticity in bipolar disorder. Expert Rev Neurother 2008;8: 1101-1113.

-22 Shirayama Y, Chen AC, Nakagawa S, Russell DS, Duman RS: Brain-derived neurotrophic factor produces antidepressant effects in behavioral models of depression. J Neurosci 2002;22:3251-3261.

23 Hashimoto K, Shimizu E, Iyo M: Critical role of brain-derived neurotrophic factor in mood disorders. Brain Res Brain Res Rev 2004;45:104-114.

24 Malberg JE, Eisch AJ, Nestler EJ, Duman RS: Chronic antidepressant treatment increases neurogenesis in adult rat hippocampus. J Neurosci 2000;20:9104-9110.

25 Duman RS, Vaidya VA: Molecular and cellular actions of chronic electroconvulsive seizures. J ECT 1998;14:181-193.

26 Einat H, Yuan P, Gould TD, Li J, Du J, Zhang L, Manji HK, Chen G: The role of the extracellular signal-regulated kinase signaling pathway in mood modulation. J Neurosci 2003;23:7311-7316.

27 D'Sa C, Duman RS: Antidepressants and neuroplasticity. Bipolar Disord 2002;4:183194.

28 Angelucci F, Aloe L, Jiménez-Vasquez P, Mathé AA: Lithium treatment alters brain concentrations of nerve growth factor brain-derived neurotrophic factor and glial cell line-derived neurotrophic factor in a rat model of depression. Int J Neuropsychopharmacol 2003;6:225-231

29 Fukumoto T, Morinobu S, Okamoto Y, Kagaya $\mathrm{A}$, Yamawaki S: Chronic lithium treatment increases the expression of brain-derived neurotrophic factor in the rat brain. Psychopharmacology (Berl) 2001;158:100106.
30 Manji HK, Quiroz JA, Sporn J, Payne JL, Denicoff K, Gray NA, Zarate CA Jr, Charney DS: Enhancing neuronal plasticity and cellular resilience to develop novel, improved therapeutics for difficult-to-treat depression. Biol Psychiatry 2003;53:707-742.

>31 Lee HY, Kim YK: Plasma brain-derived neurotrophic factor as a peripheral marker for the action mechanism of antidepressants. Neuropsychobiology 2008;57:194-199.

32 Piccinni A, Marazziti D, Catena M, Domenici L, del Debbio A, Bianchi C, Mannari C, Martini C, da Pozzo E, Schiavi E, Mariotti A, Roncaglia I, Palla A, Consoli G, Giovannini L, Massimetti G, Dell'Osso L: Plasma and serum brain-derived neurotrophic factor (BDNF) in depressed patients during 1 year of antidepressant treatments. J Affect Disord 2008;105:279-283.

33 Huang TL, Lee CT, Liu YL: Serum brain-derived neurotrophic factor levels in patients with major depression: effects of antidepressants. J Psychiatr Res 2008;42:521-525.

\34 Aydemir C, Yalcin ES, Aksaray S, Kisa C, Yildirim SG, Uzbay T, Goka E: Brain-derived neurotrophic factor (BDNF) changes in the serum of depressed women. Prog Neuropsychopharmacol Biol Psychiatry 2006;30: 1256-1260

\35 Rybakowski JK, Suwalska A, Skibinska M, Szczepankiewicz A, Leszczynska-Rodziewicz A, Permoda A, Czerski PM, Hauser J: Prophylactic lithium response and polymorphism of the brain-derived neurotrophic factor gene. Pharmacopsychiatry 2005;38: 166-170.

36 Dmitrzak-Weglarz M, Rybakowski JK, Suwalska A, Skibinska M, Leszczynska-Rodziewicz A, Szczepankiewicz A, Hauser J: Association studies of the BDNF and the NTRK2 gene polymorphisms with prophylactic lithium response in bipolar patients. Pharmacogenomics 2008;9:1595-1603.

37 First M, Spitzer R, Gibbon M, Williams J: Structured Clinical Interview for DSM-IV Axis I Disorders. Research Version. New York, Biometrics Research, 1997.

$>38$ Hamilton M: A rating scale for depression. J Neurol Neurosurg Psychiatry 1960;23:5662.

39 Young R, Biggs J, Ziegler V, Meyer D: A rating scale for mania: reliability, validity, and sensitivity. Br J Psychiatry 1978;133:429435.

40 Tramontina J, Frey BN, Andreazza AC, Zandona M, Santin A, Kapczinski F: Val66Met polymorphism and serum brain-derived neurotrophic factor levels in bipolar disorder. Mol Psychiatry 2007;12:230-231.

41 Suwalska A, Łojko D, Janik J, Cyranik H, Rybakowski JK: Sustained attention deficits in euthymic bipolar patients. Int J Neuropsychopharmacol 2008;11:228. 